DOI 10.26724/2079-8334-2021-3-77-43-48

UDC 616.155.194-02-085-048.34-053.2:614.876:313.1

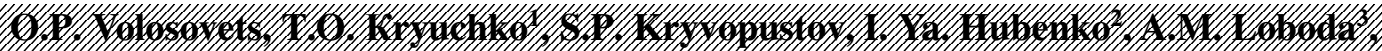

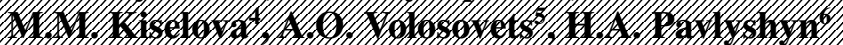

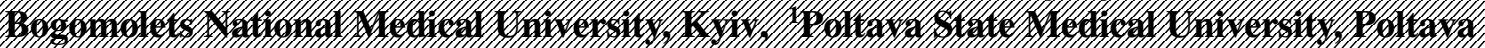

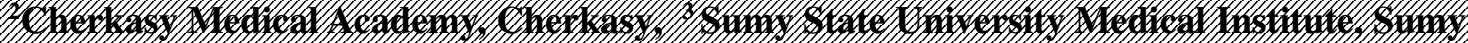

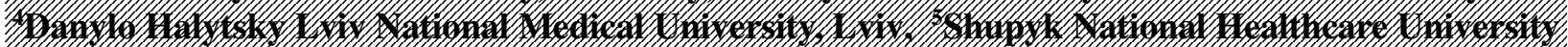

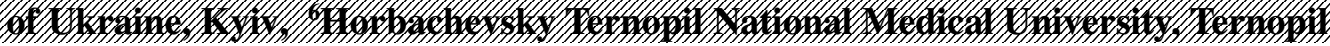

\title{
ANEMIA IN CHILDREN IN UKRAINE: A 24-YEAR RETROSPECTIVE ANALYSIS OF MORBIDITY AND PREVALENCE
}

e-mail: avolosovets@gmail.com

The article is devoted to the growth of morbidity and prevalence of anemia in children of Ukraine in the period from 1994 to 2017. The methods of the system approach and epidemiological analysis of the MOH of Ukraine's data in the period from 1994 to 2017 were used in the study. The retrospective study revealed that the incidence rate in children of Ukraine aged 0-17 inclusive increased by $31.4 \%$ and by $59.8 \%$ in the prevalence of anemia with their predominant detection in children affected by the Chernobyl accident and children constantly living in the areas with radiological control after the 1986 accident. A direct and noticeable relationship was established between the prevalence of anemia in children aged 0-14 years inclusive in 2011 and the population-weighted effective total radiation dose of the whole body in residents of different regions of Ukraine for the period 1997-2011 ( $\mathrm{p}<0.05)$, which may indicate a possible impact of the accident consequences in combination with other factors on the incidence and prevalence of anemia in children.

Key words: children, anemia, incidence, prevalence, Chernobyl disaster.

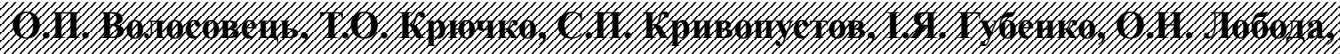

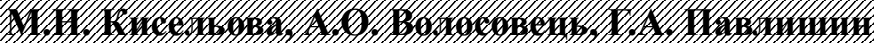

\section{АНЕМІї У ДІТЕЙ УКРАЇНИ: 24-РІЧНИЙ РЕТРОСПЕКТИВНИЙ АНАЛІЗ ЗАХВОРЮВАНОСТІ І ПОШИРЕННЯ}

Стаття присвячена зростанню захворюваності та поширеності анемії у дітей України в період з 1994 по 2017 pp. Методи системного підходу та епідеміологічний аналіз даних МОЗ України в період з 1994 по 2017 рр. були використані для досліджень. Ретроспективне дослідження показало, що в Україні у віці від 0 до 17 років включно рівень захворюваності збільшився на 31,4\%, а поширеність анемії - на 59,8 \% із переважним виявленням у дітей, які постраждали внаслідок Чорнобильської катастрофи, та дітей, які постійно проживають у районах з радіологічним контролем районів після аварії 1986 р. Встановлено прямий і помітний зв'язок між поширеністю анемії у дітей у віці 0-14 років включно в 2011 році та зваженою на населення ефективною сумарною дозою опромінення всього тіла жителів різних регіонів України за період 1997-2011 років (р<0,05), що може свідчити про можливий вплив наслідків аварії у поєднанні $з$ іншими факторами на частоту та поширеність анемії у дітей.

Ключові слова: діти, анемія, рівень захворюваності, розповсюдженість, Чорнобильська катастрофа.

The work is a fragment of the research projects "The study of pathogenetic mechanisms of the most common childhood diseases, optimization of their diagnostics and treatment", state registration No. 0117 U004683.

The incidence of anemia in children is a serious public health problem in any country. This multifactorial disease, the most common cause of which is deficiency of iron and vitamins, is frequently not diagnosed in a timely manner and leads to a number of undesirable consequences already at an early age [5-7]. Long-term chronic hypoxia negatively affects the growing body's development and may be accompanied by hypoxic dysfunction of the central nervous system. A number of studies suggest that iron deficiency anemia (hereinafter - IDA) is associated with an increased risk of convulsions in children [8].

This widespread group of diseases has recently acquired a tendency to a protracted course, especially in children from countries with unstable economies and, accordingly, with nutritional deficiencies in the child population [10]. It is obvious that the development and prognosis of the anemia course is influenced by the socio-economic state of society, especially the lifestyle and nutrition of children and their mothers before pregnancy, during pregnancy and during the period of breastfeeding, as well as environmental factors [5, 9]. Significant changes have taken place in the health status of children in Ukraine after the accident at the Chernobyl nuclear power plant (hereinafter - the Chernobyl nuclear power plant) [12].

Anemias, as well as diseases of the blood and blood-forming organs, are one of the most common pathological conditions in liquidators and victims of the accident [2,3]. A number of studies have shown the unfavorable effect of incorporated cesium on the condition and decrease in the amount of blood corpuscles in children from areas of enhanced radioecological control $[9,11]$. It is possible that the effect of the radiation factor on their health, in particular, is the result of genetic changes. The health status of 
children in Ukraine affected by the Chernobyl accident, and from areas with territories of radiological control (hereinafter - TRC) after the Chernobyl accident will for a long time be the subject of extensive research and scientific discussions about the degree of the influence of the Chernobyl disaster's consequences on it.

The purpose of the study was a retrospective analysis of changes in the prevalence and morbidity rates in children of Ukraine with anemia over 24 years of observation to assess the impact of the radiation factor on their development.

Materials and methods. An analysis was made of the prevalence and incidence of anemia in children from different regions of Ukraine from 1994 to 2017, including areas contaminated as a result of the Chernobyl accident. Methods of statistical assessment and epidemiological analysis of statistics from the Ministry of Health of Ukraine (hereinafter - the MOH of Ukraine) were used [1, 4]. A separate group of observation and assessment consisted of indices on the incidence and prevalence of anemia in children born to participants in the liquidation of the Chernobyl accident or persons evacuated from the accident zone who received the status of children affected by the Chernobyl disaster.

Methods of statistical assessment were used, in particular the Mann-Whitney signed rank U-test to compare the incidence rates of anemia in children from the same regions of Ukraine in 1994 and 2017. [1]. Spearman's rank correlation coefficient was used to analyze linear dependence and correlation, as well as to determine the degree of closeness of the relationship between population-weighted effective doses in millisieverts (hereinafter - $\mathrm{mSv}$ ) of the total body irradiation of residents in different regions of the country in the time period from 1997 to 2011 and indices on the incidence of anemia in children aged 0 to 14 years from different regions in 2011 [1,2]. For the statistical analysis of the results obtained, we used the software product STATISTICA 6.1 (StatSoft, USA) and Microsoft Office Excel - 2010.

Results of the study and their discussion. Among childhood diseases, anemia is a fairly common phenomenon. Thus, in 2017, according to the $\mathrm{MOH}$ of Ukraine, the incidence of anemia in children aged 0-17 years inclusive amounted to 89.899 or 11.8 cases per 1,000 of the corresponding child population (hereinafter - per 1,000 children). Anemias account for $96.7 \%$ of the total morbidity in children with diseases of the blood, blood-forming organs and individual disorders involving immune mechanisms (hereinafter - CD) and their proportion is increasing in dynamics - for comparison, in 1994, anemias accounted for $89.0 \%$ of the CD incidence in children. Iron deficiency anemias account for $86.8 \%$ of the total prevalence of anemia in children and $89.1 \%$ of the total number of newly diagnosed anemias, while hypoplastic anemias account for only $0.5 \%$. The proportion of the anemia incidence in children among other childhood diseases is $0.89 \%$.

Prevalence of anemia in children aged 0 to 17 years inclusive was 253085 cases or 33.2 per 1,000 children. A significant number of cases of anemia occurs as early as 1 year of life in children and is a consequence of the breastfeeding duration decrease in children and inappropriate nutrition of pregnant women, and then nursing mothers. Having enough iron, along with other trace minerals, is especially important for babies, especially those born prematurely.

Thus, in 2020 alone, 14,476 cases of anemia were registered in children of the first year of life, or 53.2 per 1,000 children, which amounted to $4.37 \%$ of all registered diseases in children of the first year of life. Anemias were more common in girls (52\% versus $48 \%$ in boys).

In 2017,7057 cases of anemia, or 18.0 per 1,000 of the corresponding child population, were detected for the first time in children affected by the Chernobyl accident, which is by 1.5 times more than the mean incidence of anemia among children in Ukraine.

Prevalence of anemia in children affected by the Chernobyl accident was 18,320 or 47.2 cases per 1,000 children, which is by $42.0 \%$ higher than the prevalence of anemia in children in Ukraine. The specific gravity of the prevalence of anemia in children affected by the Chernobyl accident is $2.0 \%$, which also exceeds this ratio in children in Ukraine as a whole.

5,170 cases of iron deficiency anemia (hereinafter - IDA) or 13.30 per 1,000 of the corresponding child population were first detected in children affected by the Chernobyl accident, which is by 1.3 times more than the mean incidence of IDA in children of Ukraine. The prevalence of iron deficiency anemia in children affected by the Chernobyl accident was 13,700 , or 35.3 cases per 1,000 children, which was by $22.1 \%$ higher than the national IDA prevalence rate in children of Ukraine.

Detection of hypoplastic anemias makes $0.43 \%$. The incidence of IDA in children affected by the Chernobyl accident was $73.3 \%$ of the incidence of all types anemia and $74.8 \%$ of the total number of detected anemia cases in children of this group, which is significantly less than the same ratio of indices in children of the country. This indirectly indicates that among this cohort of children, anemias of other genesis, including hemolytic and other deficient ones, have a relatively high prevalence. 
In $1994,118,297$ cases of anemia were first detected, being 8.98 per 1,000 children. The prevalence of anemia in children was then 275,057 , or 20.80 cases per 1,000 children aged 0 to 17 years, which was significantly lower than now.

Most cases of anemia both in 1994 and 2017 were detected in children aged 0 to 6 years inclusive $-41.4 \%$ (in $1994-38.4 \%$ ) of the total number of anemias, which indicates this age period as the most critical for the development of anemia in children (fig. 1). We consider a decrease in the proportion of the incidence rate of anemia among children in the first year of life (from $32.6 \%$ in 1994 to $26.5 \%$ in 2017), which may indicate an improvement in the observation of infants, the quality of their nutrition and care about them.

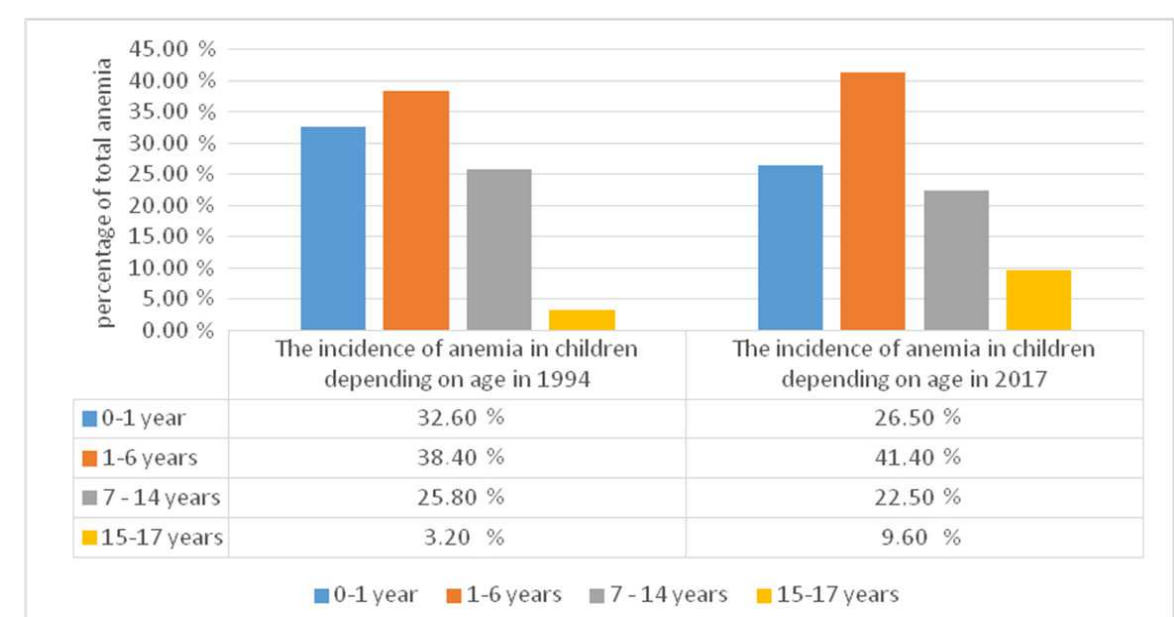

Fig. 1. Comparative characteristics of changes in the incidence of children with anemia depending on age in 1994 and 2017.

At the same time, an almost threefold increase in the detection of anemia in adolescents in dynamics over 24 years of observation is obviously associated with their nature of nutrition (passion for fast foods, etc.), a risky lifestyle, hypodynamia, prevalence of tobacco smoking and other substance abuse. In recent years, there has been a relative decrease in the proportion of detecting the incidence of anemia in children aged 7-14 years inclusively (from $25.8 \%$ to $22.5 \%$ of the total number of detected cases).

An increase in the structure of morbidity and prevalence of anemia in the proportion of IDA was established against the background of a decrease in other types of anemia. Thus, the total incidence rate of IDA in 1994 was $87.5 \%$ of the total anemia incidence, and the prevalence was $89.1 \%$. As of 2017 (the last year when medical statistics were published in Ukraine on the child population aged over 1 year), the proportion of the incidence of anemia among children increased to $89.7 \%$, and the prevalence slightly

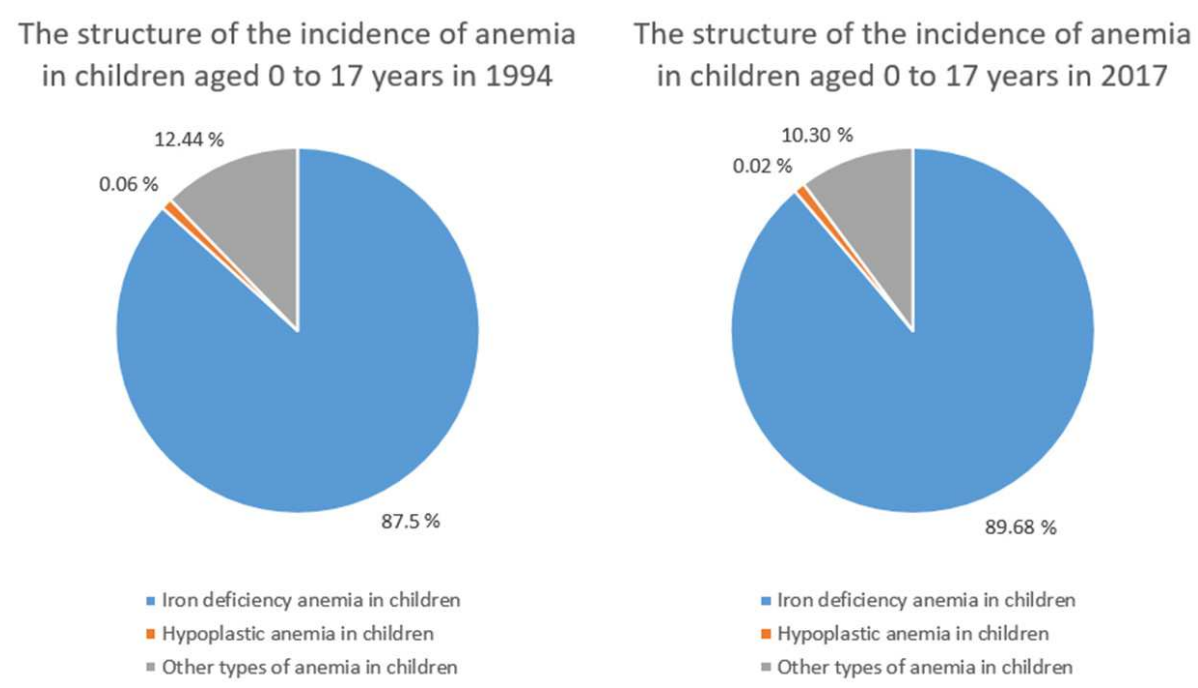

Fig. 2. Dynamics of changes in the structure of the incidence in children with different variants of anemia over the past 24 years (as a percentage).

A retrospective analysis of the incidence and prevalence of anemia in children from 1994 to 2017 of observations indicates that there is a significant increase in the detection of anemia in Ukraine. As it can be seen in fig. 3, from 1994 to 2017, the incidence rate of children in Ukraine with anemia increased by $31.4 \%$ ( $>>0.05$ ), and the prevalence of anemia increased by $59.8 \%$ (p<0.05) (fig. 3). decreased to $87.0 \%$.

That is, over 24 years of observation, there have been certain changes in the structure of anemia in children due to a slight increase in the proportion of IDA against the background of its other types' decrease. (fig. 2).

Obviously, this can only be explained by the lifestyle of modern families and the irrational nature of children's nutrition. 

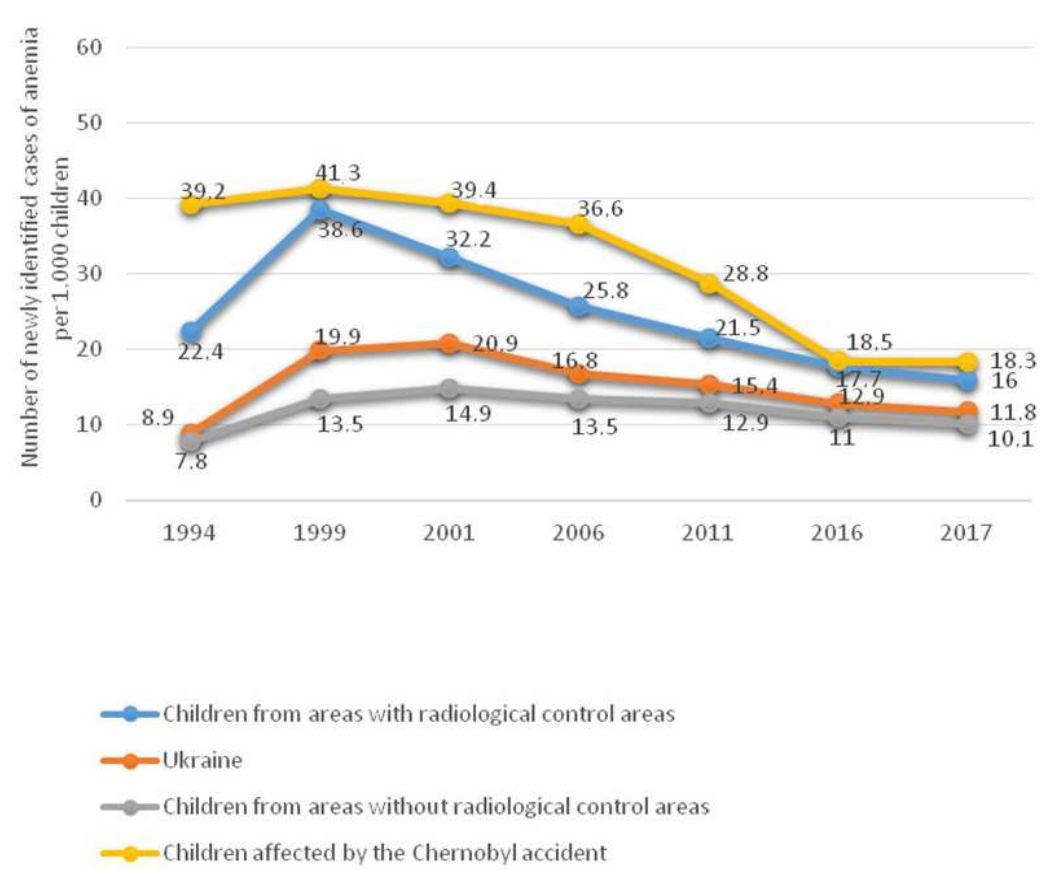

Fig. 3. Comparative dynamics of morbidity indices in children of Ukraine with anemia, children affected by the Chernobyl accident, children from areas with radiological control territories, children from areas without radiological control territories (1994-2017).

In 1994, among the leaders in the incidence of anemia in children were the following regions: Cherkasy (39.8 cases per 1,000 children), Ivano-Frankivsk (33.2), Rivne (28.1), Ternopil (21.9), Vinnytsia ( 19.7), Chernivtsi (17.8), Chernigov (15.7), Zhytomyr (14.9) and Transcarpathian (14.6) regions. Low incidence rates of CD in children were observed in the city of Sevastopol ( 0.9 cases per 1,000 children), Luhansk (2.2), Zaporizhzhya (2.2), Donetsk (2.6) regions. By that time, in 8 out of 9 main regions with $\mathrm{TRC}$, the incidence of anemia in children was higher than the all-Ukrainian index.

That is, 27 years ago, among the list of leading regions, where the largest number of children first fell ill with anemia, there were numerically more regions with TRC. It should be noted that the incidence rates of anemia among children living in regions with TRC in the early 90 s significantly exceeded national indices and the incidence of anemia among children in other regions of the country (fig. 3). This can also be explained by the fact that only 8 years have passed since the Chernobyl accident at that time, the aftereffect of post-radiation effects on the children's health still persisted, and in these regions there was a rather difficult socio-economic situation, which could not but affect the development of these pathological conditions. In general, the incidence rate of anemia in the child population from the regions with TRC decreased over 24 years of observation by $28.6 \%$, and in children from the regions without TRC it increased by $29.5 \%$ in dynamics. The morbidity rate in children, affected by the Chernobyl accident during this period, decreased by $53.4 \%$. At the same time, the all-Ukrainian index on the incidence of anemia in children during this period increased by $31.4 \%$, mainly due to the increase in the incidence of anemia in children from the areas that were not contaminated as a result of the accident.

It should be noted that during 24 years of observation in Donetsk, Lugansk, Kharkov, Zaporizhzhya, Kherson, Dnepropetrovsk and Poltava regions, which belong to the regions with developed industrial infrastructure, the greatest increase in the incidence of anemia in children was noted, respectively by $85.6 \%-295.8 \%$ compared to the incidence in 1994. Out of the regions with TRC, small increase in the incidence of anemia in children remained in the Volyn, Kyiv and Sumy regions within $2.5 \%-23.8 \%$ of the 1994 level. While in Cherkasy, Chernihiv, Ivano-Frankivsk, Rivne, and Vinnitsa and Zhytomyr regions, the incidence of anemia among children decreased, which could be associated with an improvement in the socio-economic development of these regions, the time increase from the date of the Chernobyl accident and a possible time decrease in the influence of xenobiotics, including radionuclides, on the body of children who lived in areas "contaminated" as a result of the Chernobyl accident.

Until 1999, there was an increase in the incidence rate of anemia in all studied groups: from $5.4 \%$ in the group of children affected by the Chernobyl accident to $72.2 \%$ in children living in areas with fuel dispensers. Since 2000, in children in all groups, we have observed a decrease in the incidence of anemia, which can be explained by an increase in the well-being of families, the promotion of breastfeeding and improvement in the environmental situation. 
In 2017, the incidence rate of anemia in children from regions with TRC was by $35.5 \%$ higher than the national index, and higher than the incidence rate in children from other regions - by $58.4 \%$. In all the years of observation, the incidence of anemia in children living in regions with TRC significantly exceeded the national index $(\mathrm{p}<0.05)$ and the incidence of anemia in children from regions without TRC $(\mathrm{p}<0.05)$.

In its turn, the incidence rate of anemia in children affected by the Chernobyl accident was by $17.3 \%$ higher than the same incidence rate in children from the regions with TRC and significantly higher (by $55.1 \%$ ) than the national level of incidence in this pathology. But the incidence rate of anemia in children from regions without TRC, exceeded by $81.2 \%$ (fig. 3).

The indices of the incidence of anemia in children affected by the Chernobyl accident did not differ significantly from the incidence of anemia in children permanently residing in areas with territories of radiological control $(\mathrm{p}<0.05)$. At the same time, their incidence rates for anemia throughout the 24 years of the study significantly exceeded the national level of incidence rates for children with anemia and the corresponding index for children from other regions of the country $(\mathrm{p}<0.05)$.

Over the years of observations, it can be stated that there has been a convergence of indices on the incidence of anemia in children from various regions of the country and indices of children affected by the Chernobyl accident. Indeed, in 1994, in the latter, the incidence rate of anemia exceeded the national index by 4.4 times, and the incidence rate of anemia in children from regions without TRC was by 5 times higher (fig. 3). A similar dynamics of changes was characteristic of the indices in children from the regions with TRC. Indirectly, this may indicate the influence of the consequences of the accident at the Chernobyl nuclear power plant, together with other factors, on the identification of anemias in children affected by the accident and those children who permanently lived in areas with zones of enhanced radioecological control.

Based on the results of the analysis, we also found that Spearman's correlation coefficient was 0.463 , and the correlation between the prevalence of anemia in children for the period up to 2011 and the population-weighted effective dose (in $\mathrm{mSv}$ ) of the total body irradiation in residents of different regions of Ukraine for the period of 1997-2011 was straight and noticeable ( $\mathrm{p}<0.05)$. The correlation between the incidence of anemia and the population-weighted effective dose was also direct and moderate $(\rho=0.33)$, but not reliable $(\mathrm{p}>0.05)$.

As it is seen from table 1, the highest levels of anemia among children were observed in IvanoFrankivsk, Rivne and Cherkasy regions, which have territories of radiological control after the Chernobyl disaster. Among other regions, the following regions were leaders: Chernivtsi, Transcarpathian, Kirovograd and Kherson regions.

Table 1

Comparative analysis of the incidence of anemia in children in terms of areas with areas of radiation control and other areas in descending order in 2017 (according to the MOH of Ukraine)

\begin{tabular}{|c|c|c|c|c|c|c|}
\hline \multirow[b]{2}{*}{ No } & \multirow{2}{*}{$\begin{array}{c}\text { Areas with territories } \\
\text { of radioecological } \\
\text { control }\end{array}$} & \multicolumn{2}{|c|}{ Incidence of anemia in children } & \multirow{2}{*}{$\begin{array}{c}\text { Areas without } \\
\text { territories of } \\
\text { radioecological control }\end{array}$} & \multicolumn{2}{|c|}{ Incidence of anemia in children } \\
\hline & & $\begin{array}{l}\text { Absolute } \\
\text { numbers }\end{array}$ & $\begin{array}{l}\text { per } 1,000 \\
\text { children }\end{array}$ & & $\begin{array}{l}\text { absolute } \\
\text { numbers }\end{array}$ & $\begin{array}{l}\text { per } 1,000 \\
\text { children }\end{array}$ \\
\hline & Ukraine & 89899 & 11.80 & Ukraine & 89899 & 11.80 \\
\hline 1. & Ivano-Frankivsk reg. & 7900 & 28.58 & Chernivtsi reg. & 3615 & 19.60 \\
\hline 2. & Cherkasy reg. & 5924 & 21.29 & Zakarpattia reg. & 5598 & 19.17 \\
\hline 3. & Rivne reg. & 4256 & 20.96 & Kirovohrad reg. & 2433 & 14.27 \\
\hline 4. & Vinnytsia reg. & 5183 & 17.83 & Kherson reg. & 2556 & 12.92 \\
\hline 5. & Zhytomyr reg. & 2849 & 11.78 & Kharkiv reg. & 5327 & 12.50 \\
\hline 6. & Volyn reg. & 2637 & 11.02 & Khmelnytskyi reg. & 2983 & 12.50 \\
\hline 7. & Kyiv reg. & 3351 & 10.20 & Dnipropetrovsk reg. & 7146 & 12.42 \\
\hline 8. & Sumy reg. & 1634 & 9.43 & Mykolaiv reg. & 2403 & 11.53 \\
\hline 9. & Chernigiv reg. & 1519 & 9.23 & Ternopil reg. & 2244 & 11.25 \\
\hline
\end{tabular}

The low incidence of anemia in children from the city of Kiev, Odesa, Zaporizhzhya, Lugansk and Chernigov regions can be explained both by changes in living conditions and by the failure to detect this pathology.

The data obtained indicate the probable effect of radionuclide contamination of areas with territories of radiological control on the incidence and prevalence of anemia among pediatric patients even 35 years after the Chernobyl accident, which may be associated with a long half-life (30 years) of the main radionuclides [2,9]. 
In the study of the age distribution of anemias, it was revealed that over 24 years of observation, the incidence of anemia in children aged 15-17 years increased by 3 times. In the study of the age distribution of anemias, it was revealed that over 24 years of observation, the incidence of anemia in children aged 15-17 years increased by 3 times, which is a negative trend that requires complex therapeutic and prophylactic measures on the part of a general practitioner. Most researchers associate this trend with urbanization, decreased physical activity, unhealthy diet, prevalence of tobacco smoking and other substance abuse among adolescents $[3,5,6]$.

Our retrospective analysis of the incidence and prevalence of anemia in children for the period from 1994 to 2017 showed a significant increase in this disease in other regions of Ukraine, including in areas with a developed agricultural infrastructure with significant emissions of pollutants.

The results obtained demonstrate the relevance of the problem of anemia for the child population of Ukraine. The increase in morbidity puts on the agenda the need to develop more effective therapeutic and prophylactic measures that will reduce the prevalence of this pathology, reduce the risks of its occurrence in all periods of childhood.

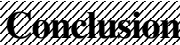

A retrospective 24-year study permitted to reveal that in children of Ukraine aged 0-17 years, inclusive, there is an increase by $59.8 \%$ in the prevalence of anemia and by $31.4 \%$ of the incidence rate, with the prevalence of detecting this pathology in children who suffered from the accident at the Chernobyl nuclear power plant and in children from areas with territories of radiological control after the accident in 1986. A direct and noticeable correlation was established between the prevalence of anemia in children aged $0-14$ years inclusive in 2011 and the population-weighted effective dose of total body exposure to the whole body of residents in different regions of Ukraine for the period 1997-2011. ( $\mathrm{p}<0.05)$.

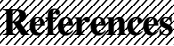

1. Antomonov $\mathrm{MYu}$ Matematicheskaya obrabotka i analiz mediko-biologicheskikh dannykh. Vtoroye izd. Kyiv: Mits "Medinform", 2018. 579 s. [in Russian]

2. Baloga VI, Kholosha VI, Evdin AI. 25 let Chernobylskoy katastrofy. Bezopasnost budushchego. Natsionalnyy doklad Ukrainy. Radiologicheskiye i meditsinskiye posledstviya Chernobylskoy katastrofy. Ministry of Emergencies of Ukraine. Kyiv: KIM; 2011. 368 s. [in Ukrainian]

3. Zabolotko VM Nadannya medychnoyi dopomohy dityam 0-17 rokiv u zakladakh okhorony zdorovya, shcho perebuvayut u sferi upravlinnya MOZ Ukrayiny: statystychno-analitychnyy dovidnyk 1994-2018. 2020. [Elektronnyj resurs]. Dostupno na: https: //www.ukrmedstat@medstat.gov.ua. [in Ukrainian]

4. Trydtsyat rokiv Chornobylskoyi katastrofy: radiolohichni ta medychni naslidky. Natsionalna dopovid Ukrayiny SI "National Research Center for Radiation Medicine of the National Academy of Medical Sciences of Ukraine". 2016. 177 s. [in Ukrainian] 5. Allali S, Brousse V, Sacri AS, Chalumeau M, de Montalembert M. Anemia in children: prevalence, causes, diagnostic workup, and long-term consequences. Expert Rev Hematol. 2017 Nov; 10(11):1023-1028. doi: 10.1080/17474086.2017.1354696. Epub 2017 Oct 12. PMID: 29023171.

6. D'Souza AM. A General Pediatrician's Approach to Anemia in Childhood. Pediatr Ann. 2020 Jan 1;49(1):e10-e16. doi: 10.3928/19382359-20191212-01. PMID: 31930418.

7. Khan L. Anemia in Childhood. Pediatr Ann. 2018 Feb 1; 47(2):e42-e47. doi: 10.3928/19382359-20180129-01. PMID: 29446792.

8. Kwak BO, Kim K, Kim SN, Lee R. Relationship between iron deficiency anemia and febrile seizures in children: A systematic review and meta-analysis. Seizure. 2017 Nov;52:27-34. doi: 10.1016/j.seizure.2017.09.009. Epub 2017 Sep 15. PMID: 28957722.

9. Lindgren A, Stepanova E, Vdovenko V, McMahon D, Litvinetz O, Leonovich E, Karmaus W. Individual whole-body concentration of ${ }^{13}$ Cesium is associated with decreased blood counts in children in the Chernobyl-contaminated areas, Ukraine, 2008-2010. J Expo Sci Environ Epidemiol. 2015 May;25(3):334-42. doi: 10.1038/jes.2013.60. Epub 2013 Sep 25. PMID: 24064533.

10. Raetz E. Advances in pediatric hematology/oncology. Curr Opin Pediatr. 2017 Feb; 29(1):1-2. doi: 10.1097/MOP.0000000000000448. PMID: 27870690. doi:10.1097/ MOP. 0000000000000448. PMID: 27870690

11. Stepanova E, Karmaus W, Naboka M. Exposure from the Chernobyl accident had adverse effects on erythrocytes, leukocytes, and, platelets in children in the Narodichesky region, Ukraine: a 6-year follow-up study. Environ. Health. 2008; 7: 21. DOI: $0.1186 / 1476-069 X-7-21$.

12. Volosovets OP, Kryvopustov SP, Volosovets TM, Abaturov OE, Kryuchko TO Changes in health status of child population of Ukraine after Chernobyl catastrophe. Wiadomości Lekarskie. 2019;LXXII (10): 1974-1976.

Стаття надійшла 28.08.2020 p. 